\title{
Once Upon a Time Was Last Night
}

\author{
Sally Breen
}

Griffith University

\begin{abstract}
ometimes it feels as if I could leech out into nothing, pull a string-just to see what $\boldsymbol{N}$ happens. I rarely think before I act and I always act before I speak. Sometimes I act and never speak again. A business card burning a hole in the front pocket of my handbag. Baking in there. Like a hard scone. I won't call. I won't message. And he might wish for me, sitting in the same bar. Pretending. Thinking this is not fun, not like it was last week. Wondering why it was all so easy the first time. Because it never pays to underestimate a slut.
\end{abstract}

Your arm in a supermarket. If I had those biceps I wouldn't be seen in sleeves either. What cold? What style? What winter? Blushing in front of 100 calorie snack packs. Telling you I'm stressed, to hide the sweat, the blood rushing to my face. You under fluorescent lights. Me holding a basket. So new, so domestic.

'Are you alone? Because last time, you walked right by me.'

'Yeah. Sometimes I do that.'

'Are you still living with your fiancé?'

'Yeah. Shrug. That's life, what about you?'

'Waiting for you to message.'

Nice. Smooth. Wish I could not blush, and think on my feet, and be that smooth. 'Friday. Friday I'll be in a hotel.' I can't remember where.

'Ok. Let me know.'

'Ok.'

You walk away. I stare at some dried apricots. 
Not another jealousy, someone else's ownership, little dramatic mis-en-scénes, played out in beer gardens, poetry readings, the dusty neon taverns we end up in. He's too hard on her. The girl. Every time. Like broken vinyl. And she walks away. But never really does. Hovering. Watching him drive his ego under her fingernails. Every time. And the guy stays just to see how long she can take it. You know the guy. The particular make of prick who only comes when his baby flinches.

Three lines racked up on a toilet stall in a fancy restaurant. Where the old women coo, appreciatively, wanting to join in, fluffing out their three-thousand-dollar suits. I flush three times for the noise we make, the three of us, the uber cool restaurant manager from the Asian fusion place across the road with the name that's not Asian that no one can pronounce, joining knock off parties after cock stroking the big end of town, the guy who buys first edition Bret Easton Ellis novels and lots of Columbian and me. Best friends. Three times because it's polite.

I don't decide to go home with the guy with the vaguely sexy association to motor racing. That just happens. After a credit card with a stripe that can never be worn down and a cocktail list that's been explored and adjudicated. That's how you walk down a street, like a whiskeyflavoured surprise-not something sugary. Not a purple lychee marshmallow in a glass. Like a machine. Like you're layered with stickers and paint and licked until the mattress with the disco sheets is saturated. And still dreaming of someone else. Because you can. Because no one bought you. Because you have a mobile and an escape plan not needed because the IT guy's father owns the apartment and there's croissants and coffee and maybe you'll call someone, a lift, a rescuer. If you want. Because you're just the happy accident they'll talk about fondly, next week.

I told everyone they were fucked. Because why the hell not? I'm a bully and a sad bitch and not a raconteur. I'm not a cool white male from last century who everyone posts the wrong videos about. Somehow no one really sees the videos where he bashes up his girlfriend and doesn't tell everyone they're fucked. Until he does. And gets away with it. No one needs it, the drama, but the sky is made of fairy floss and everyone thinks they matter, talking about their jobs, their Tinder dates, their situations that make them feel awks. Sometimes when I'm listening to people I just want to start a war. Watch us all fall into a trench. Roll around in there with some rats and blood and broken guns and un-sharpened pencils. See who comes out first. I know l'll still be sitting here in the morning. And that doesn't make me proud. It makes me victorious.

'Don't you remember that bit?' 
Why do I feel like I'm the kid now and you've morphed into a parent instead of someone I wanted (and let's face it, staring into the sun without sunglasses), maybe still want to, fuck. At least you're acting like the cooler parent now. The one who doesn't break and forgives.

'Ah of course, yeah I remember his eyes, watching us.' Our friend with the hotel room we were in, mostly uninvited. Like we should have got our own. 'He was smoking his vape and I was molesting you.'

'Inappropriately.'

'Yeah.'

'You said I could come and sleep in your spare room until your fiancé left.'

'Fuck, really?'

'Yeah. But you drew the line at fucking in the stairwell.'

'Standards.'

'Yeah, standards.'

Sometimes a thread sticks up in the middle of my lounge room and I yank it. The other night a ghost asked me to take a photograph and the photograph turned out. I look all right, better than usual and the ghost who never told me his name is just a big fucking blur of white light where no lights are. Like he's doing a streak. And some of the light is on me. That's not just a flash, I say to my mate the next day at 3pm breakfast and he says, 'You're taking selfies in the middle of the night with no one else there, you're off your head.'

I don't delete it.

And there are men in the world who'll kill 400, maybe 500, girls for profit. They can't remember. Shall we have disposable cameras at our wedding or just let everyone Insta? 